\title{
Developing Religious and Moral Values in Habitating Through Combination of Number Heads Together Model with Audio-Visual Media and Reading Aloud Method
}

\author{
Khoirul Izzah *, Darmiati, Noorhafizah \\ Master Program of Education Management, Universitas Lambung Mangkurat, Banjarmasin 70123, Indone- \\ sia
}

\section{Article history:}

Submission September 2020

Revised December 2020

Accepted December 2020

*Corresponding author:

E-mail:

izzahkhoirul112@gmail.com

\begin{abstract}
This study aims to improve the development of children's religious and moral values in memorizing short prayers using a combination of the Number Heads Together model with Audio-Visual media and the Reading Aloud method. Research settings in group B.2 Tunas Bangsa Kindergarten, West Martapura District with a total of 15 children in the 2019/2020 school year, consisting of 7 boys and 8 girls. Data obtained from observation techniques teacher activities, children, and the development of aspects of art. The indicator of the success of this study is that the teacher's activity scores $\geq 26$ with the criteria of "very good", Children's activities are categorized as successful if the classical results reach $\geq 76 \%$ with active and very active categories. and minimal child development outcomes 0 国 category as expected. Conclusion of the results of the study: teacher activity reaches a score of 31 with a percentage of $100 \%$ the category of very good, the results of children's activities classically $93 \%$ of the category is very active and the results of child development and is said to have succeeded with 15 children who obtained $>$ ? 国? Egan with an of $100 \%$ the category develops in line with expectations and develops very good.
\end{abstract}

Keywords: Religious and moral values, number heads together, audio-visual, reading aloud

\section{Introduction}

Early childhood education is a comprehensive process of fostering development and development of children aged birth to six years, which includes physical and non-physical aspects, by providing stimulation for physical, spiritual (moral and spiritual) motoric, reasoning, emotional, and social development. So, that children can grow and develop optimally. In another book, it is explained that early childhood education is an activity that is carried out properly and responsibly to create an educational interaction for early childhood aged 0-8 years and provides the possibility of developing various potentials in a more optimal direction (Mursid, 2009). Hence, it can be seen that during their childhood, children should get more attention in their growth as well as education development. Early childhood is a group of people aged 0-6 years who experience a golden period at Kindergarten age, namely the age of 4-6 years (Awalya, 2012).

At this time the child will experience extraordinary development both in the brain and physically. Children's brains will progress very rapidly (Gathercole, 1998). This is due to the many new things that children get from their environment. It is because the environment they grow up in is the first circumstance they 
encounter. Physical children will also develop rapidly, various kinds of limbs have begun to function properly (Tremblay, 2000). In this development state, the environment including parents and other older people are very important, as they will also have a part in influencing children's physical growth.

According to Suriansyah \& Aslamiah (2011), Kindergarten Education is a form of early childhood education that has an important role to develop children's personalities and prepare them to enter the next level of education. Kindergarten between 4 and 6 years of age is the most sensitive to external stimuli, where children are still happy to play and have a high curiosity making it important to receive stimuli from outside themselves to respond to various forms of play and learning patterns in the form knowledge (cognitive), skills (psychomotor), values and attitudes (affective). During this time, children in the state can easily learn new things and it should be seized well to optimize their golden age.

The golden age in early childhood cannot be overlooked, because it only happens once in a child's life (Currie, 2001). Besides, this child's golden age cannot be repeated in his life. The stimulations obtained by the child at this time will be very useful for the survival of the child in the future. According to Hurlock (1978), the first five years of a child's life are foundations for further development. Children who experience happiness at this time will be able to carry out further developmental tasks. However, if the child is under pressure at this age, the child will experience problems in further development. Thus, it is important to see the psychological aspect of children to make them always feel content and not depressed since it will affect the rest of their life.

In its development, children have several aspects of development that must be stimulated from an early age (Rohmawati, 2018). Some aspects that can be developed are intellectual, physical motor, social, emotional, language, moral, and religious aspects. Aspects of child development will be optimal if they get stimulation from the closest people starting at an early age. If aspects of child development are not stimulated from an early age, their development will be hampered (Britto et al., 2017). In this context, parents as the closest people around them should have made the initiative to stimulate and inspire the children's development.

According to Dewey (Suriansyah, 2011), educational activities are essentially a process of experience, but this experience leads to inner growth so that with this inner growth, the experience becomes the basis for growth and efforts to stimulate children's growth following their respective potentials and needs. Henceforth, education is an important aspect of children's early life and needs to get maximized the most. During this time, education that has been absorbed by children will be the base of their growth and follow them for the rest of their life. As an en experience, this growth will not be seen directly, but it will have benefit in their future personality growth. This experience is the learning of a lifetime.

Learning activities cannot be separated from the roles of teachers and children because these two components are very important in the learning process (Hidayat et al., 2019). Teachers are individuals who face directly with students through a process of instructional interaction as a vehicle for the learning process (Aslamiah, 2016). Thus, just like parents at home, teachers are the closest people owned by children at school. It can be seen that teachers play important role in developing children's educational growth. They are the educators responsible for building children's education.

The role of educators is very important (Aneja, 2014) because, as individuals, they can carry out educational actions in an educational situation to achieve educational goals. The teacher is one of the things that assesses the implementation of a learning strategy in the classroom (Zohar \& Schwartzer, 2005). Teachers who are creative, professional, and fun are required to have the skills to develop approaches and choose effective learning methods (Mulyasa, 2012). Being a creative, professional, and fun teacher is required to have the ability to develop approaches and choose effective learning methods (Suriansyah et al., 2014). This is important to have this kind of teacher around children to keep them always feel happy so they can enjoy the process of learning. 
Teachers need to do something that can manage the class well (Lee, 1995), use learning by providing exemplary and improve learning outcomes so that developments in aspects of religious and moral values can develop properly to distinguish which actions are good and bad (Afifah et al., 2019). This is not only religious and moral values, but other aspects are also important to be developed in children as early as possible. As it has been elaborated before, it is because during this time children can absorb everything fast and well, hence it is very important to start teaching various things in their learning process.

Another factor in being able to develop children's learning outcomes is the ability of teachers to deliver learning materials that motivate and can coordinate children in the class (Metroyadi \& Mardhiah, 2018). Besides, teachers need to know that every student is all very different, with varying interests, abilities, learning styles, and motivations so differentiation is frequently required to meet students' learning needs (Heilbronner, 2013). It is even better for teachers to treat their students as if they are their children with different flaws and qualities.

A component that is no less important and also plays a role in the implementation of learning is the curriculum (Hubball \& Burt, 2004). The curriculum is a set of plans or designs regarding the objectives, content, and learning materials that are used as guidelines for the implementation of educational goals. A curriculum is something that is planned as a guide to achieving educational goals. This means that all forms of learning activities carried out by the teacher must be following the curriculum so that they can effectively and efficiently lead to predetermined educational goals. "In planning and implementation, the curriculum is emphasized on the use of learning methods and strategies that allow students to master the subject matter" (Sanjaya, 2013). To achieve this goal, the government compiles an education curriculum for early childhood, the early childhood education curriculum is a set of plans and arrangements regarding objectives, areas of development, and assessment and methods used as guidelines for implementing learning activities to achieve educational goals.

Based on the description above, it can be concluded that various forms of activities in each learning process carried out by the teacher must be following the curriculum so that the learning process carried out can lead to and achieve an educational goal that has been set effectively and efficiently. Based on the implementation of learning, several aspects must be considered that must be developed in the curriculum in early childhood education: (a) aspects of the development of religious and moral values; (b) aspects of cognitive development; (c) aspects of language development; (d) aspects of social-emotional development; (e) aspects of physical-motor development; (f) aspects of artistic development.

Based on six aspects of development in the early childhood education curriculum, one of the developments that must be developed is the development of religious and moral values. The development of religious and moral values of students takes place as long as the human mind is active and there is an environment for learning. All aspects of development can be developed through the right stimulus so that the aspects of development are right on target.

The education of moral and religious values in the PAUD program is a solid foundation and very important for its existence, and if it is well embedded and imprinted in every human being from an early age, this is a good start for the education of the nation's children to undergo further education. Indonesian people uphold moral and religious values. These noble values are also desired to be spiritual motivation for this nation to carry out other precepts in Pancasila.

The idea of the need for the development of moral and religious values since childhood starting in early childhood is inspired by a concern for the reality of students and even the output of education in Indonesia today does not fully reflect a moral personality (akhlak alkarimah), which is polite. in behaving and behaving as the example has been put forward. This shows that there is something that needs to be improved in our education system, especially at the most basic level of education 
(pre-school). Therefore, as an initial effort to improve the education system in Indonesia, it is necessary to develop moral and religious values from an early age as an effort to strengthen the mental-spirituality of children (Anggun, 2016).

To develop aspects of the development of religious and moral values, language-related stimuli are needed (Aminin et al., 2018). This is following the government regulation of the minister of education and culture of the Republic of Indonesia number 146 of 2014 that "the aspect that is developed in early childhood education is the aspect of language based on the scope of accepting language, that children aged 4-5 years have a level of developmental achievement like listening to the words of others (mother tongue or another language) and understand the two commands given simultaneously. Among the language skills taught in Kindergarten (TK) Raudhatul Athfal (RA) is memorizing short prayers which are part of early religious learning. The purpose of Religious Education is to instill the seeds of faith and devotion as early as possible in the personality of students which are manifested in the development of physical and spiritual life according to the child's level of development so that they become strong Muslims, who can appreciate and practice the knowledge they have acquired. A sense of faith and devotion, one of them is, by memorizing short prayers contained in the Al-Qur'an.

In connection with the development of aspects of religious and moral values in kindergarten children, teachers are required to have understanding and skills in implementing learning activity programs (Pachauri \& Yadav, 2014). Meanwhile, in the learning process in kindergarten, the teacher also strives to present learning material to students properly so that positive and efficient results are obtained. Teachers in implementing learning must use a strategy consisting of selecting methods that are following the theme of the discussion being taught and paying attention to the use of learning models and media in improving better learning outcomes.

Based on the results of observations in Tunas Bangsa Kindergarten, the children did not pay attention to the meaning of what they memorized. This is because memorizing short prayers is important for children to memorize and do not need to pay attention to right and wrong. The problem that is often encountered in teaching, especially Early Childhood Education in memorizing short prayers is how to present the prayer memorization to young children properly so that effective and efficient results are obtained. In addition to other problems that were found, the teacher's lack of attention to variations in the use of teaching models, media, and methods to improve the quality of teaching.

Efforts to overcome children's problems in the development of religious and moral values in memorizing short prayers, researchers will involve children during learning, researchers also choose the right models, media and methods during learning activities to help children accept, obtain and achieve learning goals by well. Therefore, the researcher will use the number heads together model combined with audio-visual media using the reading aloud method to be able to overcome the problems in learning activities that occur in Group B TK Tunas Bangsa Martapura Barat.

Model Number heads together According to Daryanto (2012) is a learning model that prioritizes the existence of groups. Each student in the group has different levels of ability (high, medium, low). Meanwhile, according to other experts, the notion of Number Heads Together or numbered heads is a type of cooperative teaching with a structural approach that provides opportunities for students to share ideas and consider the most appropriate answers. Also, Number Heads Together encourages students to increase their students' spirit of cooperation. This model can be used for all lessons and all age levels of students (Lie, 2002)

Based on the above opinion, it can be concluded that the Number Heads Together learning model in the author's view is suitable for early childhood in increasing the habit of memorizing short prayers, this model emphasizes groups to increase student cooperation so that they can overcome cool children's problems with their activities.

Audiovisual technology is a way to produce or convey material using mechanical or elec- 
tronic machines to present audio-visual messages. Learning through audiovisual is characterized by the use of hardware during the learning process, such as television, tape recorders, and wide visual projectors (Arsyad, 2007). Audiovisual media is media that has sound and image elements (Saputra et al., 2018). This type of media has better capabilities, because it includes both types of media, namely audio and visual (Aqib, 2014; Dalle, 2010).

Based on this description, audio-visual media is a medium that is considered suitable for the teacher to choose in learning the memorization of short prayers in the al-quran. Audiovisual media through video helps children respond quickly because recording sounds and images in the form of the subject matter will help children understand and memorize the material correctly memorized. Children will easily accept new memorization material through listening and seeing activities that are repeated over and over again. So, it is not uncommon for Islamic education institutions, especially at the Early Childhood Education level to listen to murotals or readings of the holy alqur'an verses, because asking children to memorize seriously and seriously at an early age still has problems, given the child's concentration level. who are still at the level of playing with this media can overcome boredom in children.

The Reading Aloud method or reading aloud is an activity or activity that is a tool for teachers, students, or readers together with other people or listeners to capture or understand information, thoughts, feelings of the author (Gibson, 2008).

According to Tarigan (2008). Reading aloud or reading aloud are activities undertaken to improve reading and listening skills. By reading aloud, all students in the class will pay attention to the reading material so that when their friends read, they will know where they went wrong (Resmini \& Juanda, 2007). With this, it can solve children's problems by being able to read correctly. The reason for the researchers to use the number head together learning model in combination with audio-visual media using the reading aloud method is expected to be able to make children interested in what the teacher says, something new for children will stimulate their curiosity to learn and be interested in following learning (Spektor-Levy et al., 2013), then through the audio-visual media provided by the teacher will make learning more real, children will be more motivated and happy to memorize short surahs. This study aims to improve the development of children's religious and moral values in memorizing short prayers using a combination of the Number Heads Together model with Audio-Visual media and the Reading Aloud method in group B.2 Tunas Bangsa Kindergarten, West Martapura District.

\section{Material and Methods}

The study was conducted at TK Tunas Bangsa which is located in Sungai Rangas Village, West Martapura District, Banjar Regency. The research subjects were class B2, amounting to 15 children consisting of 8 girls and 7 boys. This class action research procedure was carried out in two cycles, each cycle consisting of two meetings. Each meeting includes four stages, namely planning, implementation, observation, and reflection. Classroom action research has important characteristics, namely that the problems raised are those faced by teachers in class (Arikunto, 2013). Data analysis through the activities of teachers, children, and the results of children's language development. Indicators of success in this study are considered successful if the teacher's activity scores $\geq 26$ with very good criteria. Children's activities reach $\geq 76 \%$ with the category of very active and the results of the child's ability to memorize short prayers if classical achieve minimal success $\star \star \star$ (Develop according to expectations) or achieve $\geq \star \star \star \star$ (develop very well).

\section{Results and Discussion}

This study succeeded in showing that improving the quality of teachers in teaching had an impact on improving the quality of children's activities and in the end improving children's development outcomes in the development of aspects of religious and moral values through memorizing short prayers through the number heads together model in combination 
with audio-visual media using the reading method aloud in group B children of Tunas Bangsa Kindergarten.

According to Susanto (2015) says that for a tutor or teacher of an early childhood education unit, it is necessary to have certain characteristics, including patient, compassionate, caring, friendly, tolerant of children, full of empathy for accepting children. they are, fair, understand feelings, forgive children, respect children, give freedom to children, create close relationships with children. In line with the opinion of Sujiono (2013), the attitude of teachers who can be friends of students also makes the ability of students to socialize more quickly. Teachers can help children who lack the confidence to learn to play with their friends. According to Suriansyah \& Aslamiah (2011) because the essence of learning is to make students achieve the desired goals, developing student personalities to achieve learning is a goal that should be considered in determining the learning strategy to be used.

The results of the research by Purwanti et al. (2018) show that the importance of the role of the teacher in observing every aspect of child development to develop optimally by improving the quality of learning in the classroom through methods learning following the characteristics of the child. So, it is clear now that a teacher in kindergarten should not only sit at the teacher's desk in front of the class, but must also participate in the games that the child is playing (Hännikäinen \& Rasku-Puttonen, 2010). Considering the extent to which the learning strategy that will be used can improve the abilities of each student, not only considering only from the point of view of the student group aspect.

According to Aisyah (2015), The Number Heads Together Learning Model is a learning model that requires students to be active in their groups. Each child in the group thinks about the answer because it is likely that each child in the group will report the results of their collaboration. Audio-visual media is the media used to deliver learning messages. In audio-visual media, two elements are united with each other, namely audio and visual. The existence of an audio element allows students to be able to receive learning messages through hearing.
Meanwhile, the visual element allows the creation of learning messages through the form of visualization (Djamarah \& Zain, 2002). Reading aloud is a method applied in the learning process, the reading aloud method was introduced by Jim Trelese in his book "The Read-Aloud Hanbook". In principle, the reading aloud method is the most effective reading method for children, because this method can condition the child's brain to feel that reading is a fun activity (Ledger \& Merga, 2018).

Based on some of the descriptions above, the teacher's activity shows a significant increase, this happens because the teacher always makes improvements to each learning activity at each meeting and also always makes improvements at the implementation of the next meeting, because the teacher feels that the results are not optimal. Therefore, teacher activity increases much better in each meeting and obtains very good criteria. This happens because the teacher knows the characteristics of a child which a teacher must have, prepares the material and media planning used and the teacher also has to master step by step the number head together model in combination with audio-visual media using the reading aloud method that can be implemented well. In this case, audio-visual media can be used as a means of developing aspects of the religious and moral values of children in memorizing short prayers (Abubakar et al., 2018). Memorizing with the help of audio-visual media makes it easier for children to remember (Roul, 2014). Before starting the activity, the teacher has prepared the equipment such as LCD, laptop, and speaker which will help the child memorize a short prayer word for word, then ask the child to memorize it in the future which previously the child was asked to memorize together in the group first. Also, the teacher is also able to manage the class properly and directed so that the improvement efforts made by the teacher are very appropriate, namely motivating children to be confident and patient, motivating children with calm and gentle delivery, motivating children by paying attention in working with their groups so that children are able and ready to memorize short do. The teacher focuses on managing the class well and is directed. Besides that, it also has a plan and 
can coordinate all children to participate in activities in developing aspects of religious and moral values in memorizing short prayers.

Children's activities also experienced an increase in the aspects of the development of religious and moral values, seen from the findings that learning activities were carried out well and the achievement of children's activities was in the less active category with a percentage of $33 \%$ and at the second meeting the category was less active with a percentage of $40 \%$, and at the third meeting, the better with the overall success indicator achieved by an average of $53 . \%$ and at the fourth meeting the maximum overall indicator has been achieved, namely an average of $76 \%$ and above. This shows that there is an increase in each meeting so that children's activation in developing aspects of religious and moral values in memorizing short prayers has reached indicators of success. Children's activation from each meeting showed a significant increase through the Number Heads Together model combined with audio-visual media using the Reading Aloud method.

In the process of learning activities at school there will be a process, namely the interaction between teachers and students, students and other students in group learning activities, in this interaction there will be a learning process which is generally defined as a process that unites cognitive, emotional, and the environment and experiences to acquire, develop or enhance make changes to knowledge, skills, values and world views. One of the aspects that must be developed in PAUD is religious and moral values. The education of religious and moral values is closely related to the character of a child, manners, the willingness to carry out religious teachings in everyday life. Then the existence of religious and moral value education in the PAUD program is a solid foundation and very important for its existence, and if this will be well embedded and imprinted in every human being from an early age, this is a good start for the education of the nation's children to undergo further education. Indonesian people uphold religious and moral values. Even this noble value is desired to be a spiritual motivation for this nation to implement other principles in Pancasila (Asmar \& Nurliana, 2014). According to Suriansyah \& Aslamiah (2011), the role of teachers in helping children acquire knowledge and skills to solve problems and resolve conflicts from children. Activities can be specifically designed to promote cooperative behavior in the classroom as well as centers of cooperative learning to make children more creative.

The numbering head together learning model combined with audiovisual media using the reading aloud method can make activities more interesting so that it makes children happier and interested in doing activities. The numbering head together model is a cooperative learning model that prioritizes the existence of groups using audio-visual media by watching full picture videos with children's voices being able to memorize short prayers enthusiastically. The advantage of this model is that it indirectly trains students to share information, listen carefully, and speak with calculations so that students become more productive in learning. The NHT learning strategy gives priority to group work over individual work so that students work in a mutually beneficial cooperative atmosphere and have many opportunities to distribute information and to improve communication skills (Kagan, 1989).

Audio-visual media is media that has sound and image elements. This type of media has better capabilities because it includes both types of auditive (hearing) and visual (seeing) media. Audiovisual media is an audiovisual aid which means materials or tools used in learning situations to assist written and spoken words in transmitting knowledge, attitudes, and ideas (Hujair, 2010). The reading aloud method is a method used by teachers in understanding material to students by emphasizing students to read text aloud.

Based on the description above, there has been an increase in children's activities, due to the accuracy of the teacher in making improvements in every meeting both at meetings $1,2,3$ and 4 in developing aspects of religious and moral values in memorizing short prayers by motivating children not to be ashamed to advance. In memorizing prayers, motivating children to be more confident in memorizing short 
prayers with motivation full of attention and love from educators all that begins. When viewed from the unique, active, and energetic characteristics of early childhood, the children enjoy participating in activities by watching memorization videos displayed by the teacher.

Then, the results of the child's ability to develop aspects of religious and moral values in memorizing short prayers through the Number Heads Together model combined with audiovisual media using the Reading Aloud method. In group B children at Tunas Bangsa Kindergarten, West Martapura District, it can be said that they have experienced development and are well implemented can be seen at every meeting. At the first meeting, individuals and classically have not reached developmental indicators with a percentage of $50 \%$, namely 2 children who have not developed with a percentage $(13 \%), 11$ children start to develop with a percentage (73\%), there is 1 child who develops according to hope with a percentage $(7 \%)$ and 1 child who occupies very well developed (7\%).

At the second meeting, an increase began to be seen, namely, 2 children had not developed with a percentage (13\%), 6 children began to develop with a percentage (40\%), and there were 6 children who developed according to the percentage ( $40 \%)$, and there is 1 child who is developing very well with a percentage $(7 \%)$. And at the next meeting, namely the third meeting, there was a very good development because there were no more children who got undeveloped gains with a percentage of $0 \%$ ), there were 2 children who started to develop with a percentage $(13 \%)$, there were 10 children who were developing according to expectations with the percentage $(67 \%)$ and there are 3 children who develop very well with the percentage (20\%). And at this fourth meeting the children have developed optimally, it seems that there are no more children who have not developed and are starting to develop, only 7 children are developing according to expectations with a percentage (47\%), and there are 8 children who are developing very well with percentage (53\%).

It can be concluded that through the Number Heads Together model, the combination with audio-visual media using the Reading Aloud method has an increase in each meeting, both from teacher activities, children's activities and the results of children's abilities in developing aspects of religious and moral values in habituating short prayer memorization. The reading aloud method is a fun activity for students (Al-Mansour \& Al-Shorman, 2011). It is not surprising if the stories or favorite reading read by the teacher or parents are more memorable to students. Also, the reading aloud method can stimulate children to read again what they have read before (McGee \& Schickedanz, 2007). The reading aloud method is very important because of the many benefits that students get. Therefore, teachers need to make an effective reading aloud program.

Based on the results and analysis of the findings data, which were carried out 4 times through habituation of memorizing short prayers through the number heads together with a model in combination with audio-visual media using the reading aloud method for group B children at TK Tunas Bangsa Kindergarten to develop aspects of religious and moral values in experiencing significant improvement. which can be seen in the following graph: 


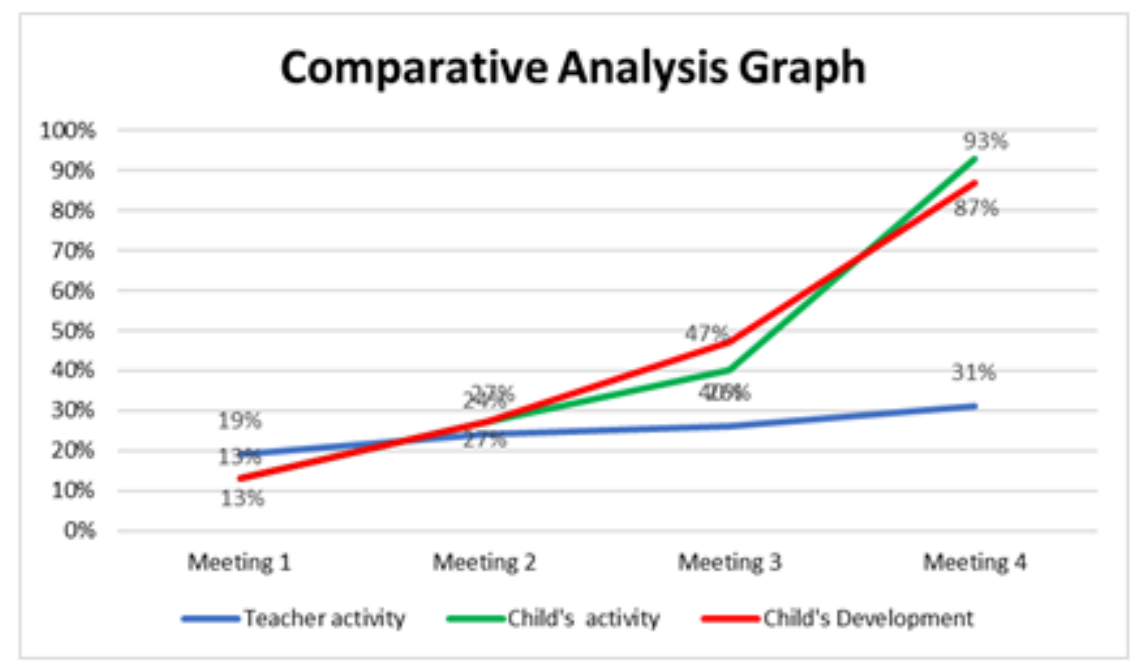

Figure 1. Graph analysis comparison of meetings 1- 4

\section{Conclusion and Recommendation}

The conclusions from the results of this study are (1) teacher activities when carrying out the learning process in developing aspects of religious and moral values in memorizing short prayers through the Number Heads Together Model Combination with Audio-Visual Media Using the Reading Aloud Method in Group B Children TK Tunas Bangsa West Martapura Subdistrict has improved very well; (2) children's activities while carrying out the learning process in developing aspects of religious and moral values in memorizing short prayers through Number Heads Together Model Combination with Audio-Visual Media Using the Reading Aloud Method in Group B Kindergarten Children Tunas Bangsa, Martapura Barat Subdistrict, almost all children are active; and (3) the results of children's abilities in developing aspects of religious and moral values in memorizing short prayers through the Number Heads Together model combined with audiovisual media using the Reading Aloud method in group B children of TK Tunas Bangsa sub-district Martapura Barat individually can be said to be successful, namely developing according to expectations and developing very well. Then, classically the results of children's abilities in developing aspects of religious and moral values in memorizing short prayers develop very well.
This research is expected to provide input to the principal in carrying out coaching for teachers so that it can improve the quality of activities in the classroom. Then, it is also as input to teachers in choosing models, media, and methods that can be used as alternatives in developing aspects of religious and moral values in early childhood education to achieve optimal results so that children in the process of learning activities in class become more interested and focused.

\section{Acknowledgment}

Thank you to the head of the program, the secretariat, and the lecturers of the Master of Teacher Education Program in Early Childhood Education at Universitas Lambung Mangkurat, Banjarmasin, who provided input and suggestions for writing this article. And thank you also to the TK Tunas Bangsa sub-district Martapura Barat Kindergarten Teacher for helping with the smooth running of this research. May we all always be in the Blessing of Allah SWT. Amiin

\section{References}

Abubakar, T. A., Abdullah, A.-H., Ali, A. R., \& Kabir, Z. M. (2018). Teachers Preference on Application of Audiovisuals in Teaching Islamic Religious Studies in Secondary Schools: A Case Study of Katsina Metropolis, Nigeria. International Journal of Academic Research in Business and Social Sciences, 8(4), 738-754. 
Afifah. N, Suriansyah. A, \& Aslamiah. (2019). Implementation of Islamic Aqidah-Based Curriculum at Khoiru Ummah's Tahfizh Plus School. j-K6EM, 2, 47-57.

Aisyah, S. (2015). Development and Basic Concepts of Child Development. Jakarta: Universitas Terbuka.

Al-Mansour, N. S., \& Al-Shorman, R. A. (2011). The effect of teacher's storytelling aloud on the reading comprehension of Saudi elementary stage students. Journal of King Saud University - Languages and Translation, 23(2), 69-76. doi:10.1016/j.jksult.2011

Aminin, S., Huda, M., Ninsiana, W., \& Dacholfany, M. I. (2018). Sustaining civic-based moral values: Insights from language learning and literature. International Journal of Civil Engineering and Technology(9), 157-174.

Aneja, N. (2014). The Importance of Value Education in the Present Education System \& Role of Teacher. International Journal of Social Science and Humanities Research, 2(3), 230-233.

Aqib, Z. (2014). Models, Media, and Contextual Learning Strategies. Bandung: Yrama Widya.

Arikunto, S. (2013). Research Procedure An Action Practice. Jakarta: PT Rineka Cipta.

Arsyad, A. (2007). Learning MediA. Jakarta: PT Raja Grafindo Persada.

Aslamiah. (2016). Building Quality Education through Improving Primary School Teacher Performance. PS2DMP, 2(1), 1-10.

Asmar, M., \& Nurliana, S. (2014). efforts to develop aspects of religious and moral values in distinguishing good and bad actions using models. Jurnal Paradigma, 9(1), 27-32.

Awalya. (2012). Benefits of early childhood education for personal development and children social. Indonesian Journal of Early Childhood Education Studies, 1(2), 1-8. doi:10.15294/IJECES.V1I2.9206

Britto, P. R., Lye, S. J., Proulx, K., Yousafzai, A. K., Matthews, S. G., Vaivada, T., \& Bhutta, Z. A. (2017). Nurturing care: promoting early childhood development. The Lancet, 389(10064), 91-102. doi:10.1016/S01406736(16)31390-3

Currie, J. (2001). Early Childhood Education Programs. Journal of Economic Perspectives, 15(2), 213-238.

Dalle, J., Haderani, \& Ulfah, R. (2010). The influence of interest, teachers, facilities and infrastructure, on the ability of students to calculate the volume and area of the geometry. Darul Ulum: Junal Ilmiah keagamaan, Pendidikan, dan Kemasyarakatan, 5(10), 3-24.

Daryanto. (2012). Innovative Learning Model. Yogyakarta: Gava Media.

Djamarah, S., \& Zain, A. (2002). Teaching and Learning Strategies. Jakarta: Rineka Cipta.
Gathercole, S. E. (1998). The Development of Memory. Journal of Child Psychology and Psychiatry, 39(1), 3-27. doi:10.1111/1469-7610.00301

Gibson, S. (2008). Reading aloud: a useful learning tool? ELT Journal, 62(1), 29-36. doi:10.1093/elt/ccm075

Hännikäinen, M., \& Rasku-Puttonen, H. (2010). Promoting children's participation: the role of teachers in preschool and primary school learning sessions. Early Years, 30(2), 147-160. doi:10.1080/09575146.2010.485555

Heilbronner, N. (2013). Creating and Delivering Differentiated Science Content Through Wikis. Science Scope, 36(5), 2434.

Hidayat, A., Hadi, S., \& Darmiyati. (2019). Development of Children's Cognitive Aspects in Matching Numbers with Number Symbols Using a Combination Model Demonstration, Make A Match Assisted by Audio Visual Media in Group B TK RA Citra Islami Banjarmasin. J-K6EM, 1-16.

Hubball, H., \& Burt, H. (2004). An integrated approach to developing and implementing learning-centred curricula. International Journal for Academic Development, 9(1), 5165. doi:10.1080/1360144042000296053

Hujair, S. (2010). Learning Media. Yogyakarta: Safiri aInsania Press.

Hurlock, E. B. (1978). Child Development Volume 1. Jakarta: Erlangga.

Kagan, S. (1989). The Structural Approach to Cooperative Learning. Educational. Educational: Leadership, 13.

Ledger, S., \& Merga, M. (2018). Reading aloud: Children's attitudes toward being read to at home and at school. Australian Journal of Teacher Education, 43(3), 124-139.

Lee, O. (1995). Subject Matter Knowledge, Classroom Management, and Instructional Practices in Middle School Science Classrooms. Journal of Research in Science Teaching, 32(4), 423-440.

Lie, A. (2002). Cooperative Learning Practicing Cooperative Learning. Jakarta: PT Grasindo.

McGee, L. M., \& Schickedanz, J. A. (2007). Repeated Interactive Read-Alouds in Preschool and Kindergarten. The Reading Teacher, 60(8), 742-751. doi:10.1598/rt.60.8.4

Metroyadi \& Mardhiah, A. (2018). Efforts to Develop Children Fine Motor Skills Through Sticking Picture Properly By Using Combination of Explicit Instruction Model And Assignment Media Utilizing Natural Materials. J-K6EM, 1, 22.

Mulyasa, H. (2012). Management PAUD. Bandung: PT. Remaja Rosdakarya.

Mursid. (2009). Curriculum and Early Childhood Education, A Community Hope. Semarang: Akfi Media. 
K Izzah., 2020 / Developing religious and moral values in habitating through combination of number heads together model

Pachauri, D., \& Yadav, A. (2014). Importance of Soft Skills in Teacher Education Programme. International Journal of Educational Research and Technology, 5(1), 22-25.

Purwanti, R., Suriansyah, A., Aslamiah, \& Dalle, J. (2018). Introducing Language Aspect (English) to Early Childhood through The Combination of Picture and Picture Model, Talking Stick Model, Flashcard Media, and Movement and Song Method In B1 Group at Matahariku Bilingual Kindergarten Landasan Ulin Tengah Banjarb. European Journal of Education Studies, 5(7), 26-34.

Rohmawati, A. (2018). Children's Social Skills Stimulation Viewed From Early Childhood Education Unit in Indonesia. International Journal of Educational Research Review, 3(3), 69 - 74. doi:10.24331/ijere.443852

Roul, S. K. (2014). Language Development of the Preschool Children: The Effects of an Audio-Visual Intervention Program in Delhi. International Journal of Instruction, 7(1), 59-74.

Sanjaya, W. (2013). Learning strategy oriented to educational process standards. Jakarta: Prenada.

Saputra, I. G., Joyoatmojo, S., \& Harini, H. (2018). The implementation of project-based learning model and audio media Visual can increase students' activities. International Journal of Multicultural and Multireligious

Understanding, 5(4),
doi:10.18415/ijmmu.v5i4.224

$167-174$. doi:10.18415/ijmmu.v5i4.224

Spektor-Levy, O., Baruch, Y. K., \& Mevarech, Z. (2013). Science and Scientific Curiosity in Pre-school-The teacher's point of view. International Journal of Science Education, 35(13), 2226-2253. doi:10.1080/09500693.2011.631608

Sujiono, Y. (2013). Konsep dasar pendidikan anak usia dini. Jakarta: PT Indeks.

Suriansyah, A. (2011). Educational Foundation. Banjarmasin: Comdes.

Suriansyah, A., \& Aslamiah. (2011). Early Childhood Learning Strategies. Banjarmasin: Comdes.

Susanto, A. (2015). Learning Theory and Learning in Primary Schools. Jakarta: Kencana Prenadamedia Group.

Tarigan, H. (2008). Reading as a Language Skill. Bandung: Angkasa.

Tremblay, R. E. (2000). The development of aggressive behaviour during childhood: What have we learned in the past century? International Journal of Behavioral Development, 24(2), 129-141. doi:10.1080/016502500383232

Zohar, A., \& Schwartzer, N. (2005). Assessing Teachers' Pedagogical Knowledge in the Context of Teaching Higherorder Thinking. International Journal of Science Education, 27(13), 1595-1620. doi:10.1080/09500690500186592 